\title{
Regulation of cell size and cell number by LANCEOLATA1 gene in Arabidopsis
}

\author{
Kiu-Hyung Cho ${ }^{1}$, Sang Eun Jun ${ }^{1}$, Soon-Jae Jeong ${ }^{1}$, Young Byung $\mathrm{Yi}^{1}$ and Gyung-Tae Kim ${ }^{1,2 *}$ \\ ${ }^{1}$ Division of Molecular Biotechnology, Dong-A University, Busan 604-714, Korea, \\ ${ }^{2}$ Environmental Biotechnology Research Center, Gyeongsang National University, Jinju 660-701, Korea
}

Received September 26, 2006 / Accepted October 31, 2006

\begin{abstract}
The processes for leaf development in dicotyledonous plants are surprisingly complex, while the mechanism of controlling and coordinating them is poorly understood. To characterize the fundamental features of the leaf development of Arabidopsis, we first attempted to isolate mutants that alter leaf morphology. Here, leaf morphological mutant of Arabidopsis, lanceolata1 (lan1) which has small and narrow leaves have isolated and characterized. To clarify the function of LAN1 in organ development, we characterized lan1-7 mutant using an anatomical and genetic approach. The lan1-7 mutant had reduced size of foliage leaves and reduced dimensions of stems. A reduction both in cell size and in cell number was evident at the cellular level in the lan1 mutant, revealing that LAN1 gene appears to affect cell division at an earlier stage and cell elongation throughout the development of leaf primordia. From the analysis of heterogeneous plant with $\operatorname{lan} 1$ mutation and $35 \mathrm{~S}-A \mathrm{G}$ transgenic plant, $A G$ gene is revealed to regulate leaf morphology under the control of $35 \mathrm{~S}$ promoter. Thus, MADS-box gene was revealed to have some relationship to that of LAN1 gene at certain stage in leaf development processes.
\end{abstract}

Key words - Cell size, Cell number, Leaf morphology, LANCEOLATA1, Arabidopsis thaliana

\section{Introduction}

The specific pattern and morphology of a given multicellular organism are attributable, in part, to mechanisms that regulate the shape, size, and number of its cells [12].

How are the patterns of cell division and cell elongation controlled with such precision? How does the embryo generate such a diversity of cell types? How do cells in such close physical proximity maintain distinct programs of development? The answers to such questions had remained elusive for decades. However, with the advance of techniques for genetic and molecular analysis, these mysteries have been unfolding. Genes acting as master regulators of cell division and cell elongation have now been identified as the main switches controlling pattern formation in plants and animals.

Our focus of this study is to identify the genes that control leaf development. In early stages of a plant's life cycle, growth is accomplished principally by initiation of new leaves by the shoot apex [4]. Subsequent shaping of leaves in later development also involves biophysical forces. Therefore, the process of leaf expansion, namely, the correlation between cell division and elongation, plays an im-

*Corresponding author

Tel : +82-51-200-7519, Fax : +82-51-200-7505

E-mail : kimgt@donga.ac.kr portant role in establishing leaf morphology [1,2]. The rates of cell division and elongation at each stage contribute to the final shape of a leaf $[13,15,16]$ and play important roles throughout leaf development. Nonetheless, the mechanisms that control these basic aspects of leaf development are poorly understood, because the pattern of growth within the lamina is surprisingly complex [13]. Several recent molecular genetic studies, including studies of cell proliferation, cell differentiation, and the cell elongation pattern in leaves, have helped us to understand the complexity of leaf shape.

The present paper reports the results of our analyses of the development of leaf cells that occur during the expansion of the true leaves of the wild type Arabidopsis, and the mutants with altered leaf morphology. Our study gives full details of the characterization of mutants Arabidopsis, named lancelolata1 (lan1). The analysis of this leaf morphological mutant should dissect the regulations of cell division and cell elongation in leaf development.

\section{Materials and Methods}

Plant growth conditions, mutant alleles and strains The following plants were used: Arabidopsis thaliana (L.) Heynh. ecotype Columbia wild type, mutant lancelolata 1 (lan1), and $t T-2$ and $t T-3$ (transgenic Arabidopsis $355-A G$ ), 
supplied by Dr. Itoh of Kyoto University).

Plants were grown onto small plastic pots with rockwool and/or vermiculite. Normally, plants were grown at $22^{\circ} \mathrm{C}$ under continuous fluorescent illumination as described previously [7]. Seven $\operatorname{lan} 1$ mutants were identified from mutants collection of Dr. Kranz (Enkheim ecotype) [3]. Allelism test was performed by crossing each allele. lan1-7 mutant allele was back crossed into the wild-type Columbia background for further analyses. To analyze double mutants, the following developmental mutant lines were used for construction: $\operatorname{lan} 1-7$ and $t T-2$ and $t T-3$ (transgenic Arabidopsis with 355 Cauliflower Mosaic Virus promoter - AGAMOUS (35S-AG), supplied by Dr. Itoh of Kyoto University).

\section{Genetic Mapping}

The marker line used for genetic mapping was W100 (an, ap1, er, py, hy2, gl1, bp, cer2, ms1, tt3) derived from ecotype Landsberg. Recombination frequencies were determined by analyzing F2 progeny using the method of Suiter et al. [14].

\section{Anatomy}

For anatomical studies, all organs were fixed overnight in FAA, which contained $5 \%(\mathrm{v} / \mathrm{v})$ acetic acid, $45 \%(\mathrm{v} / \mathrm{v})$ ethanol, and $5 \%(\mathrm{v} / \mathrm{v})$ formaldehyde and they were then dehydrated in a graded ethanol series at room temperature. Completely dehydrated tissues were preincubated in a solution of $50 \%$ (v/v) Technovit 7100 (Kulzer \& Co. GmbH Wehrheim, FRG) and in ethanol for about 1 hour and then washed in $100 \%$ Technovit resin. Next, the samples were dipped in $100 \%$ resin and the samples were incubated overnight in air. Hardening of resin and embedding in 100\% Technovit 7100 resin were achieved by the method described in the manual from the supplier of the Technovit 7100 resin. Sections of $6 \mathrm{~mm}$ thickness were cut with Histoknives (Kulzer \& Co. $\mathrm{GmbH}$ ) on an Rotary microtome HM325 (Carl Zeiss, FRG) affixed to glass slides, and stained with $0.1 \%(\mathrm{w} / \mathrm{v})$ toluidine blue in $0.1 \mathrm{M}$ phosphate buffer $(\mathrm{pH} 7.0)$ at $50^{\circ} \mathrm{C}$ for 30 seconds. Specimens were then photographed under bright-field illumination.

\section{Results}

\section{Genetic analysis of lancelolata 1 mutant}

To characterize the fundamental features of the leaf development of Arabidopsis, we first attempted to isolate mu- tants that alter leaf morphology. Seven mutants with leaves of greatly reduced size were identified from Dr. Krancz' collection and were revealed to be same locus through allelism test by crossing each other. These mutants have narrow and short leaves compared with wild type Columbia (Fig. 1 and Table 1) and was named lancelolata1 (Ian1). The wild-type gene is, thus, named LANCELOLATA1 (LAN1). The lan1-7 mutant, which was one of the severest alleles of $\operatorname{lan} 1$ mutant, was chosen for detailed studies.

The chromosomal location of the lan1 locus was determined by use of markers that represented the five linkage groups in Arabidopsis. From the result the lan1 locus was calculated to be located between py and er locus in chromosome2

In order to determine where the LAN1 gene acts, leaves, stems, and roots were measured. All the true leaves of the lan1-7 mutant are narrower and shorter than those of wild type (Fig. 1A and B). However, the growth of primary root of lan1-7 mutant was not significantly different from that of wild type (Fig. $1 \mathrm{C}$ and D).

To determine the developmental stage at which the LAN1 gene exerts its effect on leaf blade morphogenesis,
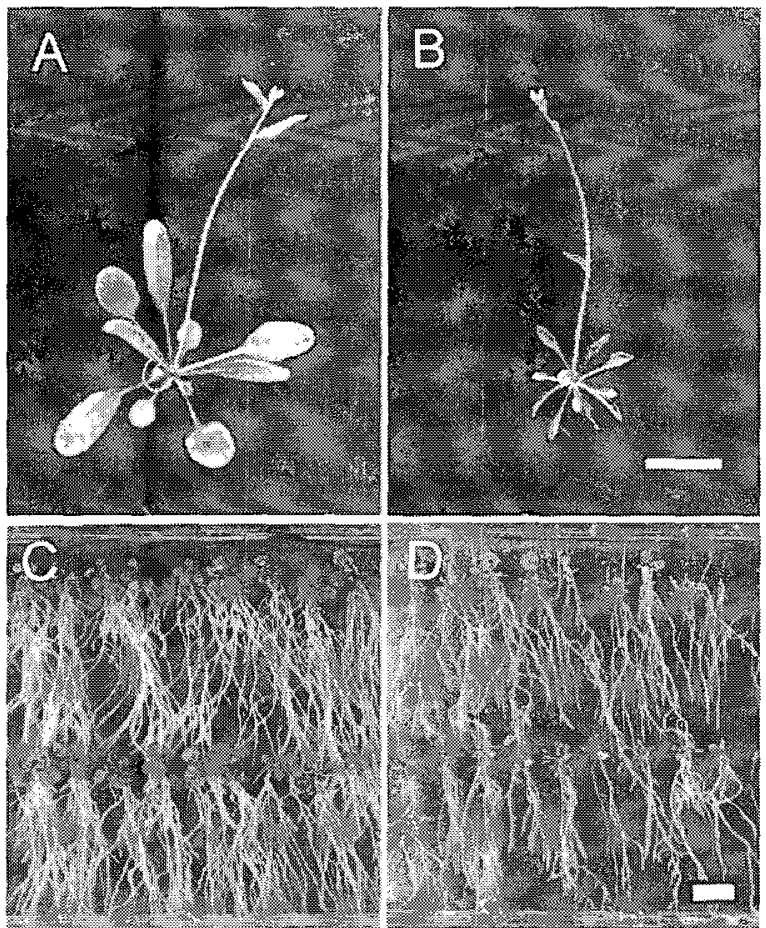

Fig. 1. Morphology of Arabidopsis thaliana plants. A,B. The gross morphology of wild-type (A) and lan1-7 mutant plant (B). The plants were photographed 4 weeks after sowing of seeds. C,D. Roots of wild-type (C) and lan1-7 mutant plant(D). Bars, $1 \mathrm{~cm}$. 
Table 1. Leaf size of the wild type, and the lan1 mutant

\begin{tabular}{crc}
\hline Direction & wild type (Col) & lan1-7 \\
\hline Leaf-width $^{\mathrm{a}}$ & $6.9 \pm 0.1(\mathrm{n}=5)$ & $2.4 \pm 0.1(\mathrm{n}=5)$ \\
Leaf-length $^{\mathrm{a}}$ & $10.8 \pm 0.7(\mathrm{n}=5)$ & $4.0 \pm 0.3(\mathrm{n}=5)$ \\
\hline
\end{tabular}

${ }^{\mathrm{a}}$ All measurements are in $\mathrm{mm}$. Size of the fifth rosette leaf was measured at fully expanded stage.

\pm , standard deviations. $n$, number of plants examined.

the growth (the width and length) of the fifth leaf of the Columbia wild type and lan1-7 mutant was analyzed at fully expanded stage. The leaf width and length of lan1 mutant showed $35 \%$ and $37 \%$ growth of wild type, respectively, in developmental stage (Table 1). The leaf expansion of lan1-7 mutant completed 15 to 18 days after sowing, whereas that of wild type still prolonged.

\section{Anatomical analysis of leaves and stems}

At least two factors, the size of cells and the number of cells, were predicted to cause the phenotype of the leaf of lan1 mutant. In order to identify which factors contributed to the phenotype of the leaf blade of $\operatorname{lan} 1$ mutant, anatomical analysis was performed in a comparison with the wild type. Throughout leaf development, the first layer of palisade cells consisted of a neatly aligned and organized arrangement of cells (Fig. 2). Therefore, these cells were used for enumeration and characterization of cells in the leaf-width and length direction on the sections. The width of palisade cells of lan1-7 mutant on transverse sections reduced and was $67 \%$ of that of wild type at fully expanded stage (Fig. 2A and B). The length and thickness of palisade cells of lan1 mutant on longitudinal sections also reduced and was $60 \%$ of that of wild type at same stage (Fig. $2 \mathrm{C}$ and $\mathrm{D}$, Table 2). Palisade cell number of the fifth rosette leaf of lan1-7 mutants aligned in the leaf-width direction and in the leaf-length direction reduced and was $55 \%$ and $63 \%$ of that of wild type, respectively (Table 2). Palisade cell number of the fifth rosette leaf of lan1-7 mutant aligned in the leaf-thickness direction was the same as in the wild type (Fig. 2). Thus, the number of total cells in the lan1-7 mutant leaf blade was smaller than in the wild type (Fig. 2). These anatomical results suggested that reduction of both size and cell number affected leaf morphological changes in lan1-7 mutant.

The length of internodes for lan1-7 mutant was not so different from that of wild type at matured stage (Fig. 1). However, the diameter was narrower than that of wild type (Fig. 2E and F). To clarify whether the defect of internodes is caused by a decrease in cell number or inadequate cell size, an anatomical study was performed of sections of first internodes of Type 2 metamer from the wild type and the lan1mutant. The diameter of pith cell of lan1-7 mutant was not so different, but the cell length was slightly increased compare to that of wild type (Fig. 2E and $\mathrm{F}$, arrow). Cell number was also reduced (Fig. 2F). These results suggest that not only cell size but cell numbers were changed by the lan1-7 mutation also in internodes, as in the leaves.

\section{AGAMOUS gene affects the morphology of curled leaf of lan 1 mutant \\ When MADS-box gene, such as AGAMOUS (AG) and APETALLA3 gene was expressed in leaf, the morphology of leaves resembled to leaves of lan1 mutant [6]. In order to investigate the relationship between $L A N 1$ and $A G$, het- erogeneous plant with lan1-7 mutation and 35S-AG trans- genic plant was constructed. Two 35S-AG transgenic lines, $t T-2$ and $t T-3$ lines were used making heterogeneous plant. One of 35S-AG transgenic plant, $t T$-2line, had leaky pheno}
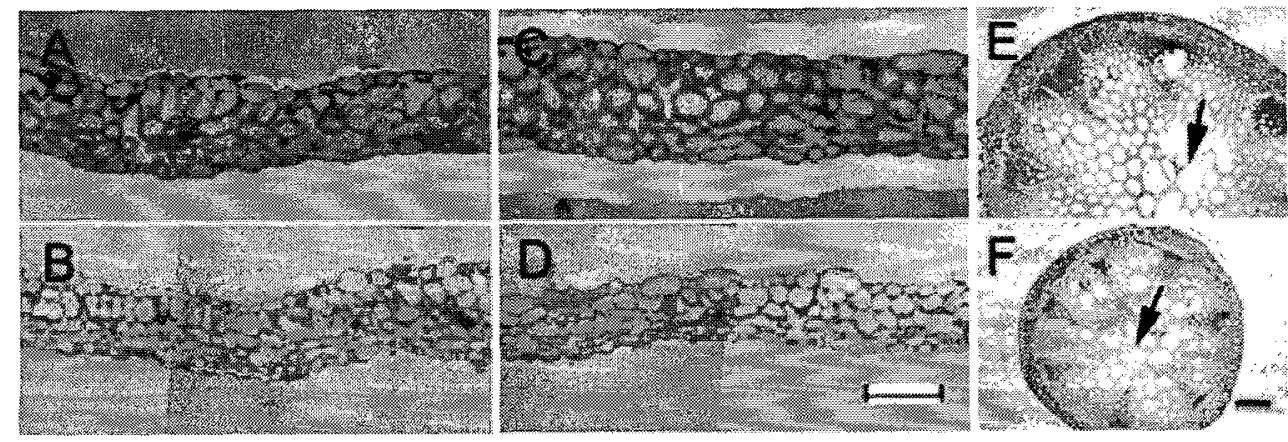

Fig. 2. Anatomical analysis of Arabidopsis thaliana plants. A,B. Transverse sections of the fifth leaf of wild-type (A) and lan1-7 mutant plant (B). C,D. Longitudinal sections of the fifth leaf of wild-type (C) and lan1-7 mutant plant (D). E,F. Transverse sections of the internodes of wild-type $(\mathrm{E})$ and lan1-7 mutant plant $(\mathrm{F})$. Bars, $100 \mathrm{~mm}$. 
Table 2. Anatomical analysis of the fifth rosette leaf of the wild type and the lan1 mutant

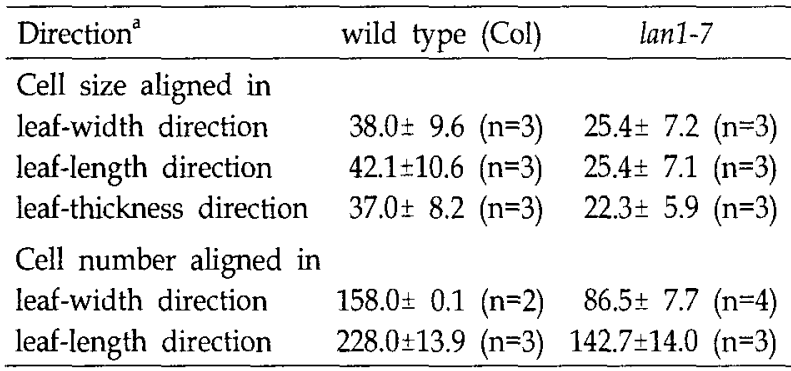

All measurements are in $\mathrm{mm}$.

${ }^{a}$ Cells in the first layer of the palisade cells aligned in each direction were analyzed. \pm , standard deviations of measurements performed on more than $150^{\circ}$ cells in each plant. $n$, number of plants examined.

type that had little bit curled leaves. The other, tT-3 line, had severely curled leaves. Leaves of all F1 progeny of lan 1-7 and $t T-2$ line were severely curled (Fig. 3D, arrow), such as in $t T-3$ line (Fig. 3C, arrow). Therefore, these data represented that function of $A G$ gene may have relationship to that of LAN1 gene at certain stage in leaf development processes.

\section{Discussion}

\section{The lan 1 phenotype and leaf development}

The recessive lan 1 mutation displays a complex phenotype in which most of the organ types of the plant except root are affected, indicating that the wild-type LAN1 gene

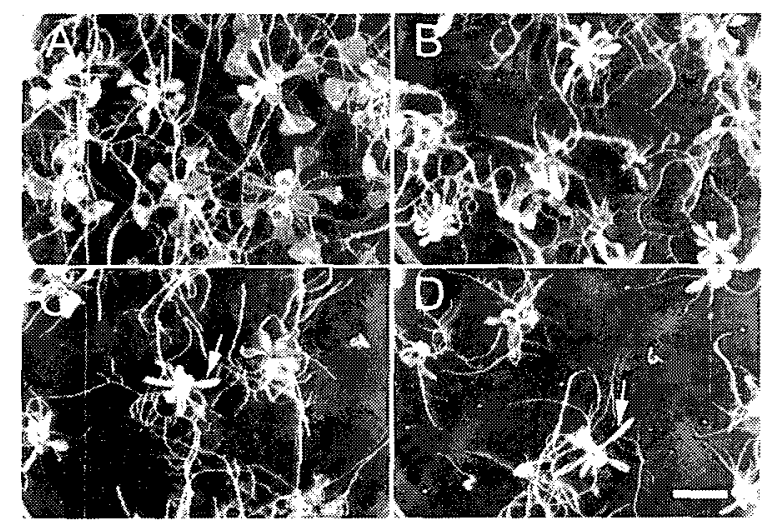

Fig. 3. Leaf morphology of Arabidopsis thaliana plants. A-D. Morphology of wild-type (A), lan1-7 mutant (B), 355$A G$ transgenic plant, $t T-3(\mathrm{C})$, and heterogeneous $\mathrm{F} 1$ plant between lan 1 mutation and 35S-AG transgenic plant, $t T-2$ (D). The plants were photographed 3 weeks after sowing of seeds on MS agar medium. Arrow indicates curled shape of leaves. Bars, $1 \mathrm{~cm}$. is necessary during various stages of development in Arabidopsis. The lan 1 plants bloom earlier and form narrow rosette leaves and their internodes than do wild-type plants. The total number of cells forming the leaf blade in the lan1 mutant appeared to be smaller than the wild type. The size of cells forming the leaf blade in the lan1mutant also appeared to be smaller than the wild type. Thus, all of the morphological characteristics of the leaves of $\operatorname{lan} 1$ mutant can be explained by a defect in cell division and cell expansion in the leaf blade.

The quantitative aspects of cell division and cell expansion are less well understood. In most cases, cell expansion precedes cell division in leaf development [1]. Thus, LAN1 gene possibly is a key regulator in the leaf development. The leaf expansion in the lan 1 mutant have stopped 15 to 20 days after sowing, whereas 35 to 40 days in the wild type. This may result from $\cdots$ a defect in Arabidopsis development not only altered cell division and cell expansion in leaf blade but also altered initiation of leaf development.

\section{LAN1 belongs to a new category of leaf develop- mental genes}

Some genes have been identified within the genetic network that controls the development of leaves of Arabidopsis. ANGUSTIFOLIA (AN) and ROTUNDIFOLIA3 (ROT3) genes are responsible for the polarity-specific elongation of leaves [7-9]. The LAN1 gene, studied here, is different from these known genes, regulating both cell division and cell elongation. curly leaf mutant has similar morphology of leaves of lan1 mutant [5]. From the result of mapping of LAN1 locus, location of CURLY LEAF (CLF) locus was revealed to be much closed to LAN1 locus. Thus, we should consider the possibility that these two mutations are in same locus. However, the function of the LAN1 gene within the network of leaf development is different from that of other known genes such KNOTTED1, AN, AN3, and ROT3 [7-12].

Although the expression of $A G$ gene was different from LAN1 gene, the morphology of curled and narrow leaf was similar between $35 S-A G$ transgenic plant and lan 1 mutant. Recently, the expression of $A G$ gene in leaf tissue is thought to be suppressed by CLF gene [5]. This suppression process indicated that $A G$ gene possibly affect the morphology of curled leaf. From the analysis of heterogeneous plant with lan1 mutation and 35S-AG transgenic plant, $A G$ gene affects the change of leaf morphology under the control of $35 S$ 
promoter. Thus, MADS-box gene was revealed to have some relationship to the morphology of curled leaf in $\operatorname{lan} 1$ mutant, directly or indirectly.

\section{Acknowledgments}

This work was supported by the Dong-A University Research Fund in 2004.

\section{References}

1. Arkebuer, T. J. and J. M. Norman. 1995. From cell growth to leaf growth: I. Coupling cell division and cell expansion. Agron. J. 87, 99-105.

2. Ashby, E. 1948. Studies in the morphogenesis of leaves. I. An essay on leaf shape. New Phytol. 47, 153-176.

3. Bork, U., K. E. Gartenbach, and A. R. Kranz. 1989. Early and late damages induced by heavy charged particle irradiation in embryonic tissue of Arabidopsis seeds. Adv. Space Res. 9, 117-121.

4. Cunninghame, M. E. and R. F. Lyndon. 1986. The relationship between the distribution of periclinal cell divisions in the shoot apex and leaf initiation. Ann. Bot. $57,737-746$.

5. Goodrich, J., P. Puangsomlee, M. Martin, D. Long, E. M. Meyerowitz, and G. Coupland. 1997. A polycomb-group gene regulates homeotic gene expression in Arabidopsis. Nature 386, 44-51.

6. Honma, T. and K. Goto. 2001. Complexes of MADS-box proteins are sufficient to convert leaves into floral organs. Nature 409, 525-529.

7. Kim, G. -T., H. Tsukaya, and H. Uchimiya. 1998. The ROTUNDIFOLIA3 gene of Arabidopsis thalianaencodes a new member of the cytochrome P-450 family that is required for the regulated polar elongation of leaf cells.
Genes Dev. 12, 2381-2391.

8. Kim, G. -T., H. Tsukaya, Y. Saito, and H. Uchimiya. 1999. Changes in the shapes of leaves and flowers upon overexpression of cytochrome $\mathrm{P} 450$ in Arabidopsis. Proc. Natl. Acad. Sci. U.S.A. 96, 9433-9437.

9. Kim, G. -T., K. Shoda, T. Tsuge, K. -H. Cho, H. Uchimiya, R. Yokoyama, K. Nishitani, and H. Tsukaya. 2002. The ANGUSTIFOLIA gene of Arabidopsis, a plant CtBPgene, regulates leaf-cell expansion, the arrangement of cortical microtubules in leaf cells and expression of a gene involved in cell-wall formation. EMBO J. 21, 1267-1279.

10. Kim, G. -T., S. Fujioka, T. Kozuka, F. E. Tax, S. Takatsuto, S. Yoshida, and H. Tsukaya. 2005. CYP90C1 and CYP90D1 are involved in different steps in the brassinosteroid biosynthesis pathway in Arabidopsis thaliana. Plant J. 41, 710-721.

11. Ori, N., Y. Eshed, G. Chuck, J. L. Bowman and S. Hake. 2000. Mechanisms that control knox gene expression in the Arabidopsis shoot. Development 127, 5523-5532.

12. Horiguchi, G., G. -T. Kim, and H. Tsukaya. 2005. The transcription factor AtGRF5 and the transcription coactivator AN3 regulate cell proliferation in leaf primordia of Arabidopsis thaliana. Plant J. 43, 68-78.

13. Steeves, T. A. and I. M. Sussex. 1989. Organogenesis in the shoot: later stages of leaf development, pp 147-175, In Steeves, T.A. and I. M. Sussex (eds.), Patterns in plant development, Cambridge University Press. New York.

14. Suiter, K.A., J. F. Wendel, and J. S. Case, 1983. LINKAGE1: A PASCAL computer program for the detection and analysis of genetic linkage. J. Hered. 74, 203-204.

15. Tsukaya, H. 2002. Leaf development. In Somerville, C. R. and E. M. Meyerowitz (eds.), The Arabidopsis Book,Rockville, MD:American Society of Plant Biologists. Available http:// www.aspb.org/downloads/arabidopsis/tsukaya.pdf

16. Tsukaya, H. 2003. Organ shape and size: a lesson from studies of leaf morphogenesis. Curr. Opin. Plant Biol. 6, $57-62$.

\title{
초록 : 애기장대의 세포 크기와 세포 수를 조절하는 LANCEOLATA1 유전자
}

\author{
조규형·전상은 · 정순재· 이영병 · 김경태* \\ (동아대학교 분자생명공학부)
}

쌍자엽 식물에 있어서 잎의 발달에 관한 과정은 매우 복잡하게 얿혀있지만, 이를 조절하는 메커니즘에 대해서는 아직 잘 알려져 있지 않다. 모델식물인 애기장대의 잎의 발달의 기초과정을 해명하기 위하여 잎의 형태이상 돌연 변이체를 이용한 접근방법을 시도하였다. 본 연구에서 잎이 작고 가는 lanceolata1 돌연변이체를 선별하였고, 이 원인유전자의 기능을 밝히기 위하여 유전학적 및 해부학적인 연구를 실시하였다. $\operatorname{lan1-7}$ 돌연변이체는 잎 뿐만 아니라 줄기도 가늘어지는 표현형을 나타내었고, 이는 세포수준에서 세포크기와 세포수의 감소에 의한 조절되고 있음이 밝혀졌다. 이 결과는 LAN1 유전자가 잎의 발달과정에서 세포분열과 세포신장을 제어하고 있다는 사실을 시사하고 있다. lan1-7 돌연변이체와 35S-AG 형질전환체와의 F1 세대의 표현형 분석을 통하여, $A G$ 유전자가 잎이 가늘고 위로 말리는 모양을 제어하고 있다는 사실이 판명되었다. 이 결과로 MADS-box 유전자가 LAN1 유전자에 의해서 제어되고 잎의 발달과정에 관여하고 있다는 사실이 판명되었다. 